\title{
Risk identification on the example of municipal sewage treatment plant
}

\author{
Magdalena Łój-Pilch ${ }^{1, *}$, Anita Zakrzewska ${ }^{1}$, and Ewa Zielewicz ${ }^{1}$ \\ ${ }^{1}$ Silesian University of Technology, Institute of Water and Wastewater Engineering, Gliwice, Poland
}

\begin{abstract}
Municipal sewage treatment plants are specific technical objects that have a serious impact on the environment and humans. Analysis and management of risk allow early detecting and eliminating threats and reduce the negative effects of risk-generating events. Only a properly conducted identification enables the correct functioning of this process. There are many methods of risk identification, some of them are of universal use, others are focused on a given type of company or activity. In the case of municipal sewage treatment plants, one should use several methods at the same time due to the complexity of processes taking place in these objects. The purpose of this paper is to present methods used to identify risks of municipal sewage treatment plants.
\end{abstract}

\section{Introduction}

Risk is a common phenomenon that occurs in every company and concerns all kinds of technical objects. It is an interdisciplinary concept, defined in different ways by representatives of various sciences, industries and spheres of economic activity [1]. However, in the most general aspect it can be defined as the probability of a specific loss due to the occurrence of adverse events [2].

Every company should take all possible actions to eliminate risk-generating situations and in the event of their occurrence take the necessary actions to reduce their negative effects. This is the aim of the risk management process. Management involves identifying and evaluating types of risks as well as measuring and continuously controlling its level. This process has been divided into stages and systematized. It encompasses the following phases: risk identification, its analysis and evaluation, its management - i.e. decision making and actions - as well as control and monitoring. Each phase of the process involves taking specific actions and drawing conclusions on their basis. These conclusions are the foundation of the subsequent stages of the process [2]. For better illustration, phases of this process and activities undertaken in each of them are presented in Table 1.

\footnotetext{
* Corresponding author: magdalena.loj-pilch@polsl.pl
} 
Table 1. Stages of the risk management process [2].

\begin{tabular}{|c|c|}
\hline Stages & Actions taken and the resulting findings \\
\hline Risk identification & $\begin{array}{l}\text { - identification of risk types, } \\
\text { - determination of the cause of risk, } \\
\text { - identification of risk-affected entities, }\end{array}$ \\
\hline Risk analysis & $\begin{array}{l}\text { - determination of the threat level of a given } \\
\text { risk to the company, } \\
\text { - determination of the "destructive" force - } \\
\text { the negative impact of a given threat, } \\
\text { - determination of risk analysis methods, } \\
\text { - defining risk management tools,, }\end{array}$ \\
\hline Risk assessment & $\begin{array}{l}\text { - } \text { measurement of the real risk level, } \\
\text { determination of the company's ability } \\
\text { to manage risk (in the absence of such } \\
\text { capabilities, taking steps to acquire them) } \\
\text { - defining possible variants of management } \\
\text { analysis of costs and expenditures } \\
\text { of individual variants } \\
\text { choosing the best variant for a given } \\
\text { company }\end{array}$ \\
\hline $\begin{array}{l}\text { Risk management: } \\
\text { decisions and actions }\end{array}$ & $\begin{array}{l}\text { - defining the priority of using particular tools } \\
\text { applying the optimal combination of the } \\
\text { management variant and the tools used }\end{array}$ \\
\hline Control and monitoring & $\begin{array}{l}\text { - assessment of the effects of actions taken } \\
\text { - modifications of the management process to } \\
\text { make it more efficient } \\
\text { - further use of effective variants and tools }\end{array}$ \\
\hline
\end{tabular}

Identification of risk on which the authors of this paper decided to focus is the first phase of the management process. Its main purpose is to determine what threats occur in the examined object, what are the reasons of their occurrence and to forecast the likely consequences of these events. This stage essentially consists in observing and understanding the mechanisms of risk emergence [3].

\section{Types of risk in a municipal sewage treatment plant}

The municipal sewage treatment plant is a specific object whose main purpose is to treat sewage in such way that the product discharged to the receiver meets legal requirements. The treatment involves physical, biological and chemical processes [4]. It is therefore natural that the multitude of cleaning stages, their specification and the number of devices used cause a large number of risk-generating situations. In the functioning of technological line one can distinguish the following risks [5]:

- qualitative - causing insufficient sewage treatment,

- operational - causing changes in the technological process - and in extreme cases even the breakdown of the treatment process; it connects with the qualitative risk,

- ecological - causing changes in the receiver, pollution of the natural environment; it connects with the qualitative and operational risk,

- financial - causing financial losses connected with the elimination of the emerged damage, paying of penalties and compensations; it connects with all of the abovementioned risks. 
It should be remembered that in addition to its specificity, a sewage treatment plant is also the company, which has to deal with the types of risk distinctively connected with its functioning. Therefore, during identification, it should also take into account [2]:

- economic risk,

- legal risk,

- organizational risk,

- political risk,

- technological risk.

It is also necessary to take into account a risk of the human factor. It should be dealt with in two aspects: risks for people present in the treatment plant and a human, in this case an employee, as a source of potential risk [6].

The authors of this paper focused on the identification of risks and factors that pose a direct threat to the technological line of a treatment plant. Therefore, only the phenomena causing qualitative, operational and ecological risk as well as financial risk related to them all were analyzed during the research.

\section{Methods of risk identification}

Depending on the type of company and the processes taking place in it, the activities undertaken or the stage of functioning of the examined object, an appropriate identification method should be adopted. Among the methods of identification described in the literature one can distinguish:

- Method of analyzing historical data - based on data provided by the company's manager [7],

- Delphi method - where the knowledge and experience of experts in a given field is used to determine the probability of occurrence of a given event [8],

- Checklist method - it is used to determine whether specific risks have been considered in the project; checklists are effective provided that they are of general nature [9].

- Brainstorming method - is characterized by a large number of probable riskgenerating phenomena [8],

- Environmental method - which identifies the risk arising from the present and future states of external environment of the company [10],

- Method of creating process diagrams - it consists in determining the course of a given process and identifying potential threats, their causes and probable effects [10].

During the risk identification, all methods described above were used in the examined treatment plants. The whole identification process was based on the method of data analysis provided by the manager of the treatment plant.

\section{Results of identification}

111 different risk-generating situations appeared in the examined object. Among them there were 36 threats. Each identified threat was described by the reason of its occurrence, the effects it caused and the type of risk that it could potentially pose. The diagram below (Fig. 1.) illustrates the most frequently identified types of risks. 


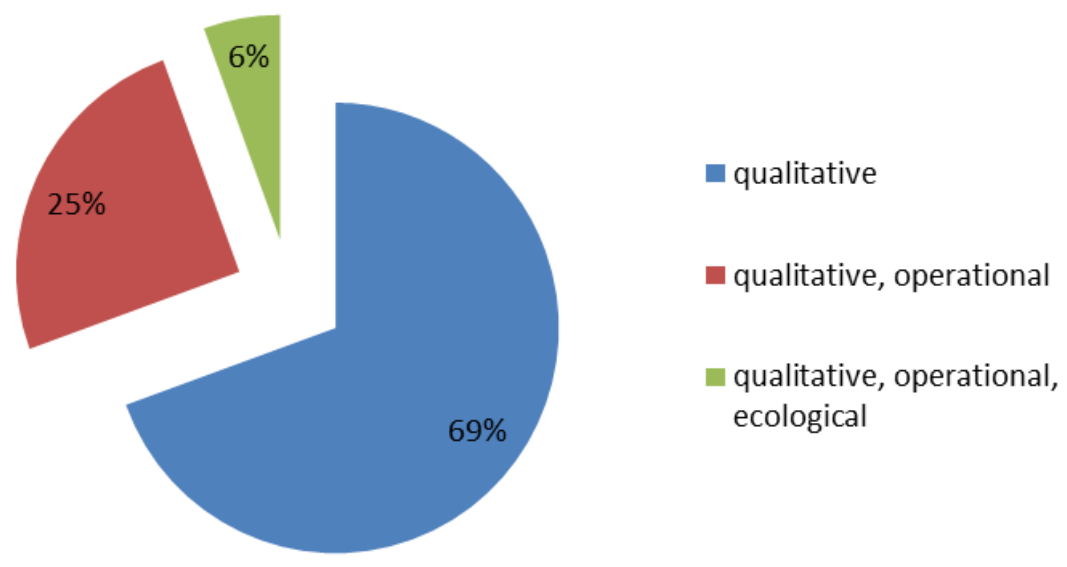

Fig. 1. Types of risks in the examined object.

The most frequent were threats that may pose a qualitative risk. These were the events affecting the level of sewage treatment and possibly causing deterioration of sewage quality at the outflow. It should be noted that in the examined object, in the analyzed period of time ( 3 years), the quality indicators for discharged sewage were not exceeded. This proves that correct designing, construction, operation and maintenance of the treatment plant significantly reduces the possibility of risky situations. In addition, the method of treatment plant operation and maintenance, in particular the keeping of worksheets, repair cards and a technological notebook, where all events are recorded and then the circumstances of their occurrence are analyzed, practically prevents the appearance of threats. The only riskgenerating events are the ones which in extremely unfavorable circumstances may create a real threat to the essential functions of the object. Table 2 presents some examples of identified risk-generating events.

Table 2. Examples of risk factors for selected elements.

\begin{tabular}{|c|c|c|c|c|c|}
\hline Device & Event & Factor & $\begin{array}{l}\text { Type of } \\
\text { risk }\end{array}$ & Effect & $\begin{array}{c}\text { Action } \\
\text { taken/proposed }\end{array}$ \\
\hline Bar screen & clogging of bars & outside & quality & $\begin{array}{c}\text { impeded } \\
\text { sewage flow }\end{array}$ & bars cleaning \\
\hline Grit chamber & $\begin{array}{l}\text { large dump of } \\
\text { greasy sewage }\end{array}$ & external & qualitative & $\begin{array}{c}\text { clogging of } \\
\text { grease } \\
\text { chamber } \\
\text { outflow }\end{array}$ & $\begin{array}{l}\text { unclogging the } \\
\text { outflow }\end{array}$ \\
\hline $\begin{array}{l}\text { Activated } \\
\text { sludge } \\
\text { chamber }\end{array}$ & $\begin{array}{l}\text { emergence of } \\
\text { filamentous } \\
\text { bacteria }\end{array}$ & internal & $\begin{array}{l}\text { qualitative, } \\
\text { operational }\end{array}$ & $\begin{array}{l}\text { formation of } \\
\text { scum layer }\end{array}$ & $\begin{array}{l}\text { breaking the } \\
\text { scum layer and } \\
\text { actions aimed } \\
\text { at stopping } \\
\text { bacteria } \\
\text { development }\end{array}$ \\
\hline
\end{tabular}




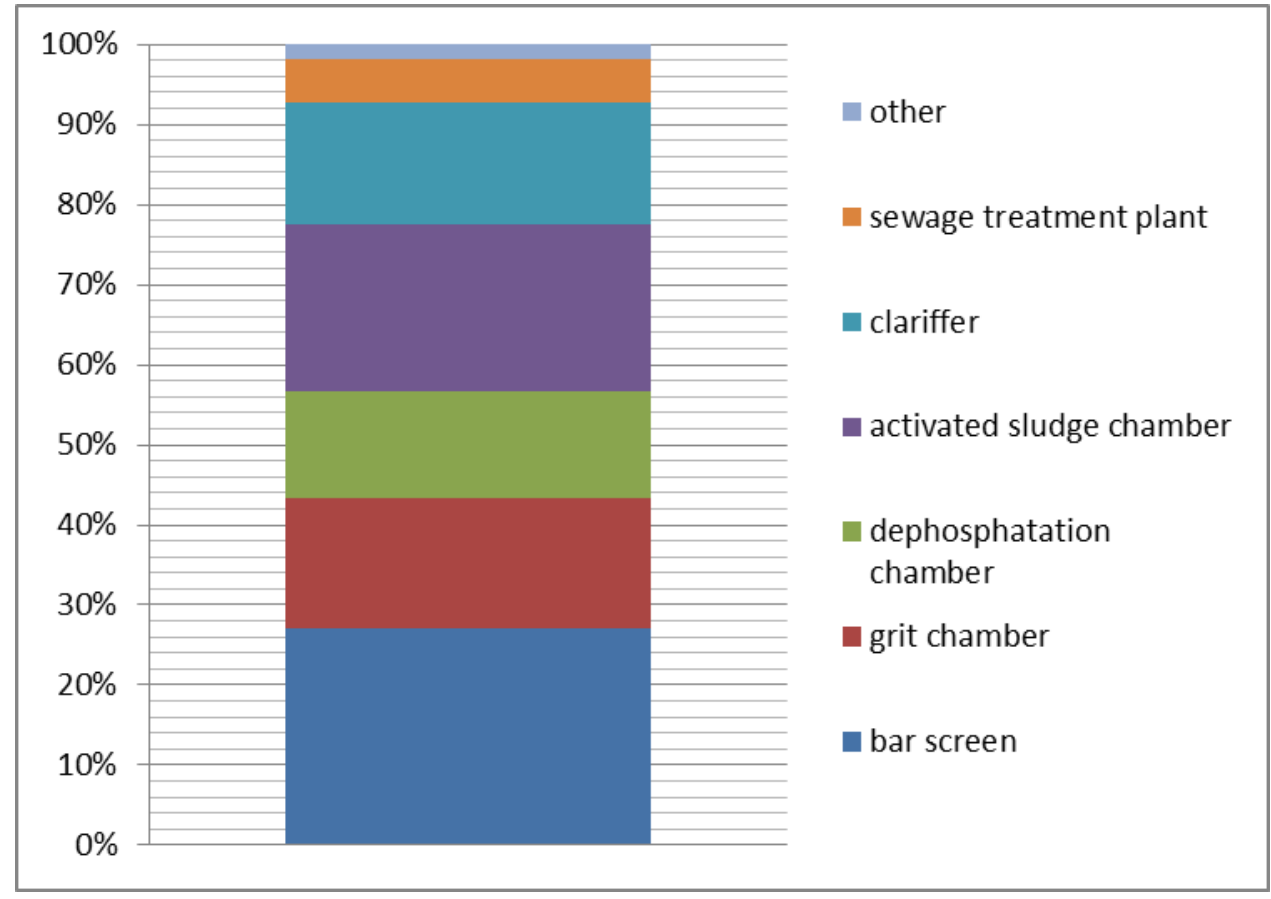

Fig. 2. Threats in individual objects.

The conducted analysis shows that in the examined treatment plant the devices most exposed to threats were bar screens (30 risk-generating situations) and the activated sludge circulation chamber (23 risk-generating situations). These devices are located at the beginning of the plant's technological line, so they are particularly encumbered not only in a hydraulic way and by pollutants load, but also by possible accidental pollutants. The purpose of the bar screen is to stop all large pollutants, thereby protecting further elements of the technological line from damage, while the activated sludge chamber is the first device aimed for biological sewage treatment. The results of the research carried out for the treatment plant in question have shown that these devices are the most exposed to threats, which is related to the function they perform in the technological line of the sewage treatment plant.

\section{Conclusions}

Risk identification is the essential and necessary stage of the risk management process in each company. At the beginning of this stage of actions, one should become familiar with the specificity of the examined object, learn the mechanisms of its operation and the processes taking place in it. Correct identification also depends on the selection of the appropriate method. In the case of complex technical objects, such as municipal sewage treatment plants, one may find that it is necessary to use several methods. It should be remembered that risk management, and by the same the identification of threats, should be a continuous and systematic process.

This work was supported by Research Funds For Young Researchers awarded to the Institute of Water and Wastewater Engineering of the Silesian University of Technology No. BKM / 554 / RIE$4 / 2017$. 


\section{References}

1. J. Zawarska, Zarządzanie i Finanse 10 (2012), pp. 65-75

2. T.T. Kaczmarek, Zarządzanie ryzykiem. Ujęcie interdyscyplinarne, Difin (2010)

3. M. Łój-Pilch, A. Zakrzewska, E. Zielewicz, Badania i Rozwój Młodych Naukowców w Polsce 2017, Materiały Konferencyjne - jesień, Część III - Wrocław (to be published)

4. T. Żaba, A. Królikowski, J. Królikowska, Inżynieria Ekologiczna 24 (2011), pp. $215-225$

5. R. Iwanejko, S. M. Rybicki, Gaz, woda i technika sanitarna 02/2008 (2008), pp. 10-13

6. B. Kirwan, Applied Ergonomics, 29,3 (1998), pp. 157-177

7. A. Kumpiałowska, Skuteczne zarzadzanie ryzykiem a kontrola zarzadcza $w$ sektorze publicznym, Wydawnictwo C.H.Beck (2011)

8. A. Korombel, Ryzyko $w$ finansowaniu działalności inwestycyjnej metoda project finance, Difin (2007)

9. D. Sobocińska, Wykorzystanie list kontrolnych $w$ procesie zarzadzania ryzykiem projektów informatycznych (2003)

10. A. Korombel, Zeszyty Naukowe Uniwersytetu Szczecińskiego nr 640, Finanse. Rynki Finansowe. Ubezpieczenia nr 38 (2011), pp. 707-715 